\title{
How Shall We Thank Thy Merit?
}

\author{
Michael A. Ashby • Leigh E. Rich
}

Received: 4 December 2013 / Accepted: 9 December 2013 /Published online: 3 January 2014

(C) Springer Science+Business Media Dordrecht 2014

KING Oh! welcome most, most welcome to my Arms, What Gratitude can thank away the Debt, Your Valour lays upon me? ...

THUMB When I'm not thank'd at all, I'm thank'd enough, I've done my Duty, and I've done no more (Fielding 1731, I.iii.1-6).

Although Henry Fielding's play, The Tragedy of Tragedies, or the Life and Death of Tom Thumb the Great, was known primarily for its political satire in its day, the heroic character of Tom Thumb - diminutive in height only_ has long endured. Described by Fielding as a "little Hero with a great Soul" (Fielding 1731, under "Dramatis Personae") and a "Godlike Creature" (Fielding 1731, I.iii.7), Thumb exemplifies both bravery and modesty, the latter of which is a "Candle to [his] Merit/It shines itself, and shews thy Merit too" (I.iii.8-9).

Like the king in Thumb's tale, we at the Journal of Bioethical Inquiry owe a debt to many often unrecognized champions who ask for no thanks in return. They serve their duty to the important scholastic process of

\section{A. Ashby}

Palliative Care and Persistent Pain Services, Royal Hobart, Hospital, Southern Tasmania Area Health Service, and School of Medicine, Faculty of Health Sciences, University of Tasmania, 1st Floor, Peacock Building, Repatriation Centre, 90 Davey Street, Hobart, TAS 7000, Australia

e-mail: michael.ashby@dhhs.tas.gov.au

\section{E. Rich $(\bowtie)$}

Department of Health Sciences (Public Health), Armstrong

Atlantic State University, 11935 Abercorn Street,

Savannah, GA 31419, USA

e-mail: leigh.rich@armstrong.edu peer review, sharing their expertise and offering their time to ensure quality in the production of knowledge and to continue the professional dialogue that is so essential to the academic enterprise.

While we know that there is perhaps no gratitude that "can thank away the Debt," we at the $J B I$ would like to continue an annual tradition begun two years ago in our 8(4) issue of formally thanking our peer reviewers and all those who have made the Journal of Bioethical Inquiry possible. Please find below the names of all who have served as a peer reviewer for one or more articles over the past year and a quarter, from September 2012 to December 2013.

We also wish to thank all of our contributors, advisory board members, editorial board chair, managing and copy editors, executive committee members, associate editors, publishing and production editors, members of the publishing team, and-most of all-readers of the $J B I$.

Thank you for your continued efforts and another interesting and enlightening year at the Journal of Bioethical Inquiry.

Aaron Fellmeth

Abdallah Adlan

Adam Feltz

Ainsley Newson

Alex John London

Alexander Lautensach

Alice Dreger

Alma Rae

Andrea Lynne Nicki

Andrea Whittaker

Anna Rangan 
Anne Gallagher

Aysha Akhtar

Ben Gray

Bernadette Tobin

Björn Bentlage

Brian Hazelton Walsh

Brooke Adam

Charles Douglas

Chris Degeling

Christina Schües

Christopher F.C. Jordens

Christopher James Ryan

Colleen Cartwright

Cynthiane Morgenweck

David Isaacs

Diane Perpich

Diego Silva

Diekema Douglas

Don Rose

Duujian Tsai

Edwina Light

Eleanor Milligan

Emma Kowal

Floris van den Berg

Giuliana Fuscaldo

Hudson Henry Birden

Ian Olver

Imke Tammen

Israel Berger

Jackie Leach Scully

Jacqueline Davies

James Stanescu

Jane Johnson

Janet Malek

Jennifer Parks

Jessica Shaw

Joel Frader

John Anthony

Jonny Anomaly

Joseph Kras

Judi Malone

Julie Letts

Justin Denholm

Karmen Stankov

Katrina Bramstedt

Kenneth Robert Abbey

Kerreen Reiger

Kerry Bowman

Kim McLeod
Kimberly Strong

Lance Wahlert

Lisa Parker

Louise Baur

Lynley Anderson

Marie Edwards

Markus Vinnari

Matti Hayry

Meina Lee

Merrilyn Walton

Mianna Lotz

Michael Souter

Mike Climstein

Miles Little

Morgan LeFay Holmes

Muireann Quigley

Neil Levy

Nicholas Sandovnikoff

Nicole Gerrand

Nikola Stepanov

On-Kwok Lai

Patricia Marck

Paul Cheung

Paul Ndebele

Pekka Jokinen

Philip Rosoff

Randi Gunhildstad

Raymond DeVries

Roberto Adorno

Roberto Forero

Robin Pierce

Ross Halpin

Samia Hurst

Sandra Bradley

Sascha Callaghan

Sheryl de Lacey

Simon Quilty

Simon Walker

Simon Woods

Siobhan O'Sullivan

Soren Holme

Steven Jackson

Steven Miles

Subrata Chattopadhay

Susan MacCallum

Susan Palmer

Thom Brooks

Thomas David Harter

Timothy Murphy 
Tina Cockburn

Tuvesson Hanna

Vera Dalqvist

Veronique Boscart

Wendy Rogers

\section{References}

Fielding, H. 1731. The tragedy of tragedies; or the life and death of Tom Thumb the great. London: J. Roberts. http://d.lib. rochester.edu/camelot/text/fielding-tragedy-of-tragedies. 